\title{
Difficult biliary cannulation: should we always try a second ERCP after a failed needle-knife fistulotomy?
}

\author{
Victor Kalil FLUMIGNAN ${ }^{1}$, Marina Garcia SEIKE², Victória Soares de SOUZA², \\ Matheus Iguera CIRQUEIRA2 ${ }^{2}$ Ana Beatriz SILVA ${ }^{2}$ and Everson Luiz de Almeida ARTIFON ${ }^{3}$
}

ABSTRACT - Background - A successful bile duct cannulation is a prerequisite for the realization of endoscopic retrograde cholangiopancreatography (ERCP). When biliary cannulation is not possible, needle-knife fistulotomy (NKF) can be performed. However, when biliary access is not successfully achieved even after performing NKF, it is possible to interrupt the procedure, and repeat the ERCP after a short interval. Objective - The aim of this study is to analyze if repeating an ERCP after a short interval of 48 hours is effective in achieving biliary access after an initial NKF was unsuccessfully performed. Methods - A total of 1024 patients with a naive papilla, that underwent ERCP between the years of 2009-2019, were retrospectively reviewed. Difficult biliary cannulation was identified in 238 of these cases and NKF was performed. Success of biliary cannulation, NKF success at the first and second ERCPs, the associations between the type of the papilla, biliary dilatation, and overall success of NKF and adverse events rates were evaluated. Results - Biliary access was initially achieved in $183(76.8 \%)$ cases. Of the $55(23.1 \%)$ remaining cases a second attempt was performed after 48 hours, and biliary access was successfully achieved in $46(83.6 \%)$ of them. The overall success of NKF after the first and second ERCP, the success rate was $96.2 \%$. Papilla located out of its normal position was related to a minor chance of success at NKF $(P<0.05)$. Conclusion - We conclude that when biliary access is not achieved after the performance of a NKF, a second attempt is safe and effective and should be attempted.

Keywords - ERCP; catheterization; endoscopic sphincterotomy.

\section{INTRODUCTION}

Endoscopic retrograde cholangiopancreatography (ERCP) is the standard diagnostic and treatment procedure for various pancreatic and biliary diseases ${ }^{(1)}$. A successful bile duct cannulation is a prerequisite for the realization of the ERCP and even in experienced hands, biliary cannulation can fail in 5-20\% of the cases ${ }^{(1-5)}$. When biliary cannulation is not possible, additional techniques are necessary to continue the procedure and access the common bile duct ${ }^{(6)}$. Despite the improvements in the gastrointestinal scopes and emergence of new catheters and guide-wires over the last decade, a standard technique has not been defined for difficult biliary cannulation. Needle-knife precut sphincterotomy, needle knife fistulotomy (NKF), transpancreatic sphincterotomy, double-guidewire and rendezvous are the most frequently performed techniques in this situation ${ }^{(5,7)}$.

Pancreatitis is the most common ERCP complication, with overall rates of $5-7 \% 0^{(8)}$. Some studies suggest that needle knife precut sphincterotomy is related to higher rates of complications including perforation, bleeding, and pancreatitis ${ }^{(6,9,10)}$, and in comparison, it's been reported that NKF is related to a lower risk of $\mathrm{PEP}^{(1)}$. The European Society of Gastrointestinal Endoscopy (ESGE) recommends the NKF be used as the preferred technique for precutting ${ }^{(11)}$.

Although NKF is a safe and effective technique in difficult biliary cannulation, it can also result in cautery related edema and tissue necrosis, that will not allow biliary access ${ }^{(12)}$. When this occurs, some endoscopists abandon the procedure and change their strategy to percutaneous procedures or EUS access, for example. It has been observed that after a short time, with the resolution of the edema and tissue necrosis, the biliary access becomes feasible in the most part of the cases. In our center, we opted to repeat the ERCP 48 hours after the first NKF. The aims of this study are to analyze NKF for its overall safety, effectiveness, and its use in successful biliary access when it used as a second attempt after primary failure.

\section{METHODS}

A total of 1115 ERCP realized between the years of 2009-2019 in Hospital Santa Marcelina, were analyzed. In this observational retrospective study informed consent was obtained from all the patients. The study was also approved by the Ethical Committee of the Institution. From the total, 91 patients were excluded due to: previous ERCP in 37 (40.6\%) cases and surgical altered anatomy, such as Roux-en-Y gastrojejunostomy, or Billroth II gastrectomy, in $54(59.4 \%)$ cases. The remaining 1024 cases were then analyzed. The procedures were performed under deep sedation, or general anesthesia, depending on patient status, and all of them were executed by an advanced endoscopy fellow under supervision of an experienced endoscopist. 
Difficult biliary cannulation was defined as a failure to achieve biliary access after 10 minutes of attempted cannulation, five contacts to the papilla or five pancreatic duct cannulations. When difficult biliary cannulation was defined, NKF was indicated as the first option. NKF using a Needle-Knife papillotome (Micro-Knife XL, Boston Scientific Corp, Natick, Mass), and pure cutting current, was performed at 11 o'clock position initiating at the top of the infundibulum, with a slowly downward movement, creating an 3-5 $\mathrm{mm}$ incision, until bile or a whitish mucosa of bile duct, was seen. Then the catheter was exchanged for a regular sphincterotome and biliary access was performed with a guide wire and confirmed by contrast injection. Following the successful biliary cannulation, the fistulotomy orifice was usually expanded with the regular sphincterotome. When deep cannulation was not possible even after the NKF, the procedure was then suspended, and a new ERCP was performed 48 hours later. At the second ERCP attempt, with the resolution of edema, tissue necrosis, and absence of clots the procedure was usually performed successfully with a regular sphincterotome, and the biliary access was easily achieved with cannulation of the fistulized area. If this was not possible, a second NKF was attempted, usually at the same location where the previous incision was performed.

The primary outcome of this study is to analyze the success rate of biliary access following NKF, and its success at the second attempt when biliary access wasn't achieved during the first ERCP. Secondary outcomes analyze the association between the type of the papilla, biliary dilatation and NKF final success rate. We also compared If the ERCP indications were related to final NKF success, overall procedure complications and CBD success rate cannulation.

Informed consent was obtained from all patients and the study was approved by the Institutional Ethical Committee of Hospital Santa Marcelina.

The statistical analysis was performed using the SPSS 22 for Windows software. All tests were performed with $95 \%$ confidence $(\alpha=0.05)$. The analysis was performed with chi-square test and Logical Regression.

\section{RESULTS}

Of the 1024 patients, $64.88 \%$ were female, and the average age of the patients was \pm 58 years with standard deviation of 19 years. The most common ERCP indication was choledocholithiasis which occurred in $70.2 \%$ of the patients, followed by pancreatic cancer $(12.8 \%)$, cholangiocarcinoma $(4 \%)$, papillary neoplasm $(3 \%)$, gallbladder neoplasm $(2.5 \%)$, hepatic metastasis $(1.4 \%)$, and other less frequent etiologies $(6.1 \%)$.

Cannulation of the biliary ostium was successfully performed in $786(76.7 \%)$ patients. In $238(23.3 \%)$ patients, primary cannulation was not possible and NKF was performed, as shown in TABLE 1. From the 238 NKF performed, biliary access was achieved initially in $183(76.8 \%)$ cases. Regarding the remaining $55(23.1 \%)$ cases where biliary access couldn't be achieved at the initial procedure, a second attempt was performed after an interval of 48 hours. With the resolution of the edema, tissue necrosis, and clots, at the second attempt the biliary access was feasible in the majority of patients. The remaining 55 cases were then submitted to the second ERCP, and success was achieved in $46(83.6 \%)$ of them, as seen at FIGURE 1. When considering the overall success of NKF after the first and second ERCP, the success rate was $96.2 \%$.
TABLE 1. Fistulotomy frequency.

\begin{tabular}{lcc}
\hline Fistulotomy & Frequency & Percent \\
\hline No & 786 & 76.7 \\
Yes & 238 & 23.3 \\
Total & 1024 & 100.0 \\
\hline
\end{tabular}

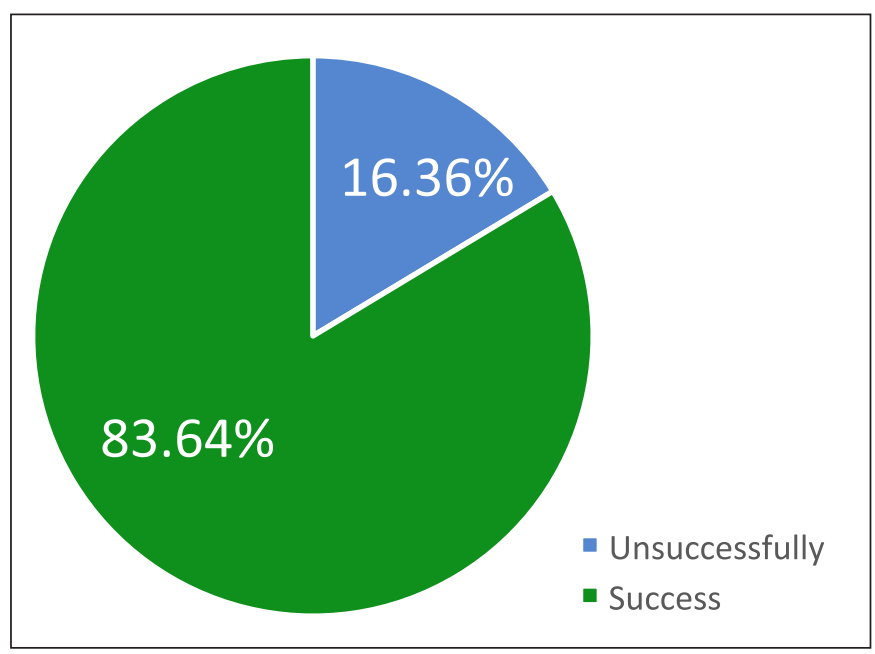

FIGURE 1. Success in the second nkf approach.

When applying or testing the chi-square to verify an association between papilla classification and success in fistulotomy, there was a significant association between them $(P<0.05)$. We observed in TABLE 2 that regular papilla (polypoid), protruding papilla, peri/ intra-diverticular papilla, with greater frequency were found with success at fistulotomy. When we look at the classification "located out of its normal position", we can see that the percentages are much more balanced, different from the other classifications, showing that when the papilla is out of its normal position, there is a greater chance of an unsuccessful fistulotomy. When associating success at fistulotomy with etiology of the ERCP, there was no evidence for an association between them $(P>0.05)$, this data can be seen in TABLE 3.

TABLE 2. Final success of fistulotomy regarding the type of papilla.

\begin{tabular}{lccc}
\hline & \multicolumn{2}{c}{$\begin{array}{c}\text { Sucess at } \\
\text { fistulotomy }\end{array}$} & $\begin{array}{c}\text { Chi-square test } \\
(\boldsymbol{P} \text {-value* }\end{array}$ \\
\cline { 2 - 3 } $\begin{array}{l}\text { Clapsification of the } \\
\text { papilla }\end{array}$ & No & Yes & \\
\hline Regular (polypoid) papilla & $5.6 \%$ & $94.4 \%$ & \\
Protruding papilla & $5.4 \%$ & $94.6 \%$ & \\
$\begin{array}{l}\text { Peri/Intra-diverticular } \\
\text { papilla }\end{array}$ & $0.0 \%$ & $100.0 \%$ & $\left(0.000^{* *}\right)$ \\
$\begin{array}{l}\text { Located in the third } \\
\text { duodenal portion }\end{array}$ & $41.7 \%$ & $58.3 \%$ & \\
\hline
\end{tabular}

*Chi-square test (95\%confidence). **Statistical significance. 
TABLE 3. Final success of fistulotomy in relation to the final diagnosis.

\begin{tabular}{lccc}
\hline \multirow{2}{*}{ Final diagnosis } & \multicolumn{2}{c}{ Sucess at fistulotomy } & \multirow{2}{*}{$\begin{array}{c}\text { Chi-square test } \\
(\boldsymbol{P} \text {-value* }\end{array}$} \\
\cline { 2 - 3 } Cho & $0.0 \%$ & $14.0 \%$ & \\
\hline Cholelithiasis & $8.3 \%$ & $36.7 \%$ & \\
Mirizzi syndrome & $0.0 \%$ & $0.5 \%$ & \\
Pancreatic cancer & $66.7 \%$ & $27.4 \%$ & \\
Cholangiocarcinoma & $8.3 \%$ & $7.9 \%$ & $13,593(0.093)$ \\
Papilla neoplasm & $0.0 \%$ & $5.6 \%$ & \\
Liver metastasis & $0.0 \%$ & $2.3 \%$ & \\
Gallblader cancer & $8.3 \%$ & $3.3 \%$ & \\
Others & $8.3 \%$ & $2.3 \%$ & \\
\hline
\end{tabular}

*Chi-square test (95\% confidence). **Statistical significance.

When evaluating the presence of biliary dilatation and successful NKF performance, there was no evidence of a relationship between them. The chi-square test and the Logical Regression mode did not show statistical significance in the analysis of the relationship $(P>0.05)$, and this is shown in TABLES 4 and 5.

TABLE 4. Analysis of the association between the presence of biliary dilation and the success of the procedure.

\begin{tabular}{lccc}
\hline Biliary dilatation & \multicolumn{2}{c}{ Resolution } & $\begin{array}{c}\text { Chi-square test } \\
(\boldsymbol{P} \text {-value* }\end{array}$ \\
\cline { 2 - 4 } Mild dilatation & No & Yes & \\
\hline Moderate dilatation & $6.3 \%$ & $14.6 \%$ & $39.6 \%$ \\
Marked dilatation & $2.8 \%$ & $12.3 \%$ & $3,990(0.263)$ \\
Normal diameter & $2.5 \%$ & $19.8 \%$ & \\
Total & $13.8 \%$ & $86.2 \%$ &
\end{tabular}

*Chi-square test (95\% confidence). **Statistical significance.

TABLE 5. Association between the presence of biliary dilation and the success of the procedure - logistic regression analysis.

\begin{tabular}{lcccc}
\hline $\begin{array}{l}\text { Biliary } \\
\text { dilatation }\end{array}$ & Resolution & & & \\
\cline { 2 - 5 } & Yes & & & \\
\hline Mild dilatation & $14.6 \%$ & 1 & & \\
$\begin{array}{l}\text { Moderate } \\
\text { dilatation }\end{array}$ & $39.6 \%$ & 1.001 & $(0.584-1.714)$ & 0.998 \\
$\begin{array}{l}\text { Marked } \\
\text { dilatation }\end{array}$ & $12.3 \%$ & 0.681 & $(0.364-1.275)$ & 0.230 \\
$\begin{array}{l}\text { Normal } \\
\text { diameter }\end{array}$ & $19.8 \%$ & 1.240 & $(0.659-2.334)$ & 0.505 \\
\hline
\end{tabular}

*Wald test (95\% confidence).
When analyzing adverse events related to NKF (considering the first and the second procedures), from the $238 \mathrm{NKFs}, 13 \mathrm{had}$ complications: 5 (38.4\%) of them had pancreatitis, 5 (38.4\%) had bleeding, and $3(23 \%)$ had other complications, achieving a postNKF adverse event rate of 5.4\%, as seen in TABLE 6 .

TABLE 6. Needle-knife fistulotomy (nkf) complications.

\begin{tabular}{lcc}
\hline NKF complications & Frequency & Percent \\
\hline Acute pancreatitis & 5 & $2.1 \%$ \\
Bleeding & 5 & $2.1 \%$ \\
Other complications & 3 & $1.26 \%$ \\
Total & 13 & $100.0 \%$ \\
\hline
\end{tabular}

\section{DISCUSSION}

In 1980 Seigel first introduced pre-cutting to improve success rate at ERCP, followed then by the invention of the needle knife by Huibregtse, that promoted different precut techniques in order to achieve bile duct cannulation in difficult $\mathrm{ERCPs}^{(6,12)}$. The needle-knife fistulotomy (NKF) technique is defined as the use of a needle-knife catheter to perform an incision in the roof of the papilla, achieving biliary access, when difficult biliary cannulation is present. Studies showed that NKF is effective in achieving biliary access when difficult biliary cannulation is present ${ }^{(13)}$. Recent studies defend its early implementation during challenge cases ${ }^{(14)}$. Another common technique is the needle-knife precut sphincterotomy when the incision is initiated from the papillary orifice. This technique is, otherwise, related to pancreatic duct trauma, and greater rates of $\mathrm{PEP}^{(15)}$. However, it is also well known that the difficult biliary cannulation by itself is an independent risk factor for $\mathrm{PEP}^{(16)}$, and there is no consensus on whether or not needle-knife precut results in higher rates of PEP pancreatitis.

The NKF employs an incision at the intraduodenal segment of the CBD creating a choledochoduodenal fistula, avoiding the contact to the papillary orifice and leaving the papillary sphincter partially intact ${ }^{(2)}$. This segment is usually above the papilla orifice and can be executed with a Needle-Knife catheter with movements in the downward direction in relation to papilla or the upward or cephalic direction, using electric current (cut, coagulation or blend) until the $\mathrm{CBD}$ is seen. A guidewire is then introduced into the CBD and after the radiological confirmation of successful biliary access, the fistulotomy orifice can be expanded by using a regular sphincterotome. In FIGURE 2, a classic sphincterotomy after an initial successful cannulation is shown. In FIGURE 3, after failed cannulation, a needle-knife catheter can be seen prior to the start of the incision in the roof of the papilla, in the proper position to perform the fistulotomy NKF, and in FIGURE 4 a scheme showing the steps of a NKF can be seen.

After the recognition of a biliary difficult cannulation, an early NKF was performed. Over the 10 -year period of this retrospective study, 1024 cases were analyzed and 237 NKF were performed. These cases were always performed by an advanced endoscopy fellow and supervision was performed by a senior expert endoscopist. Of the 237 cases, success was initially achieved in biliary access in $78.6 \%$ of the patients. When biliary access was not possible even after NKF, a new ERCP after a short interval 


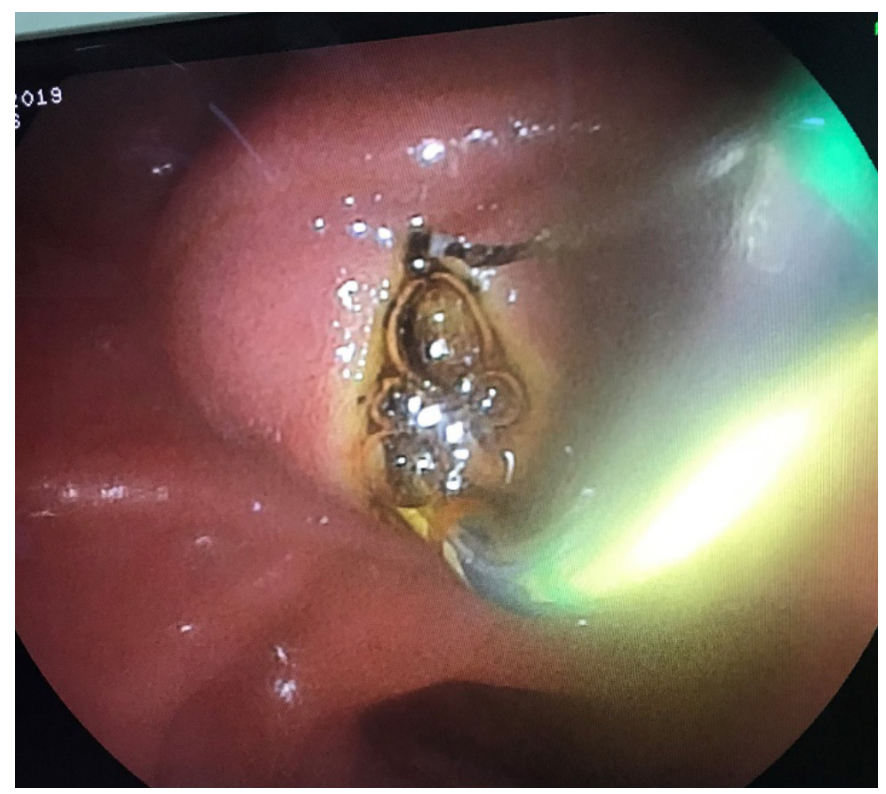

FIGURE2. Classic sphincterotomy.

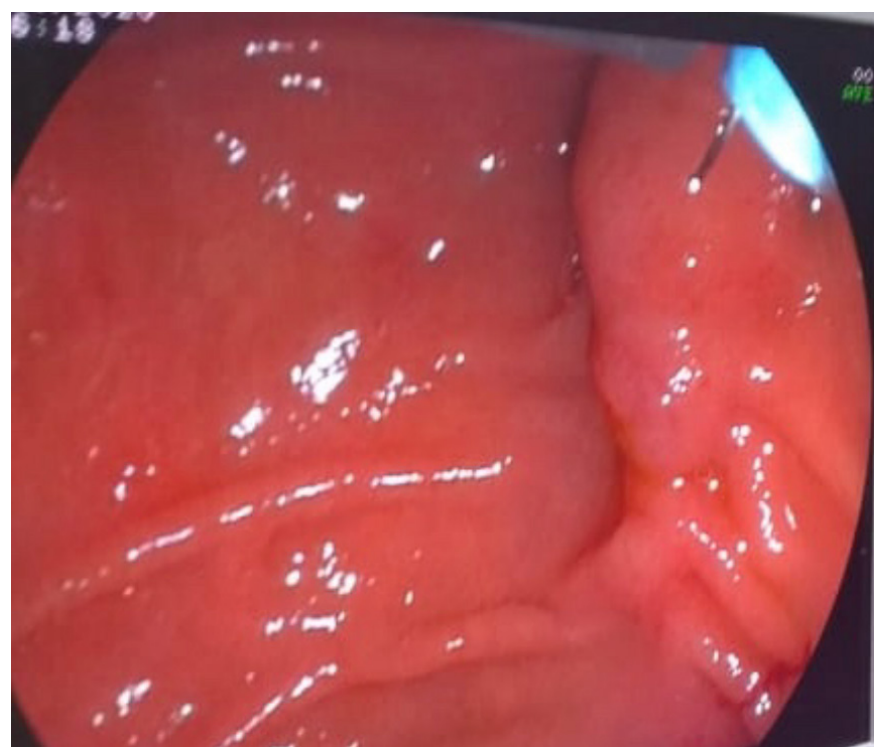

FIGURE 3. Needle knife catheter positioned in the roof of the papilla prior to attempting a nkf procedure.

of 48 hours was performed. Success rate of the ERCP after the short interval was $83.6 \%$, reaching an overall NKF success rate of $96.2 \%$. The success of ERCP after a short interval can be explained due to the improvement of the edema and inflammation $^{(17)}$, that allows better visualization of the site, and a safe and effective biliary cannulation.

Cannulation of the papilla ostium rates usually reaches 80 $95 \% 0^{(1-5)}$. In our study a_cannulation rate of $76.7 \%$ can be justified by the fact that all procedures were performed by an advanced endoscopy fellow, and when cannulation was not possible, usually a NKF was precociously indicated, considering that this could prevent PEP and the fact that the fellows needed to perform the technique to achieve proficiency. There are studies that shows that the presence of a trainee may compromise cannulation success rates ${ }^{(18)}$.

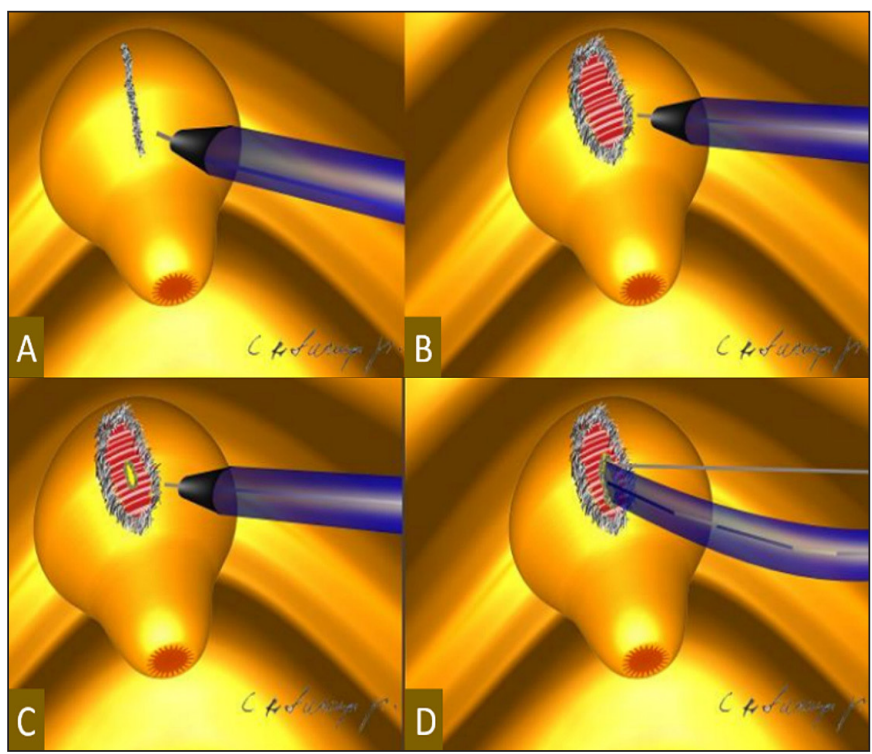

FIGURE 4. Needle-knife fistulotomy technique: (A) incision in the roof of the papilla; (B) exposure of the sphincter muscle layer; (C and D) dissection and access to $\mathrm{cbd}^{(5)}$.

There are several descriptions of the macroscopic papillary appearance, but there is no consensus on which is the best classification $^{(19)}$. In the present study they were classified in four types: regular (or polypoid), protruding, peri-diverticular and located out of its normal position (usually at third duodenal portion). In our analysis when the papilla was located out of its normal position, there was a relation with lower success at NKF performance. Periampullary diverticula are present in 10-20\% of all ERCP cases and are considered for some authors as an impediment to the ERCP procedure $^{(20,21)}$. However, in our study the presence of periampullary diverticula did not influenced in the NKF overall success or complication rates.

The standard post-ERCP complication rate is $3-10 \% \%^{(22)}$. In our study the overall adverse-events rate was $5.4 \%$. Pancreatitis is the most common post ERCP complication and results in an increase in the overall cost of care ${ }^{(16,23)}$. In this analysis pancreatitis was responsible for $78.6 \%$ of all ERCP complications, followed by bleeding in $12.5 \%$ of cases, and other less frequent causes in $8.9 \%$. However, when analyzing the post-NKF complications, we can see that pancreatitis rate was only $38.4 \%$, much less than in the overall post-ERCP complication rate $(78.6 \%)$, suggesting that an early approach with NKF may prevent pancreatitis. Some studies show that the use of a plastic pancreatic stent is related to a decreased occurrence of PEP in high-risk patients ${ }^{(16)}$. It can be endoscopically withdrawn after a few days or spontaneously migrate, which can be confirmed by X-ray, and avoid another endoscopic procedure.

Because this is a retrospective study, there are limitations including selection bias. A prospective study analyzing the performance of NKF may be superior but it would take much longer to perform a similar analysis.

\section{CONCLUSION}

In conclusion, NKF is feasible, safe, and can be attempted after a short interval of 48 hours if the first ERCP attempt was not successful. 


\section{ACKNOWLEDGEMENTS}

We would like to thank Dr Hélio Tanaka for his help and advice.

\section{Authors' contribution}

Flumignan VK: conceptualization, methodology, project administration, writing-original draft, and writing-review and editing. Seike MG, Souza VS, Silva AB and Cirqueira MI: data curation. Artifon ELA: formal analysis.

\section{Orcid}

Victor Kalil Flumignan: 0000-0003-3591-1237.

Marina Garcia Seike: 0000-0002-1268-955X.

Victória Soares de Souza: 0000-0002-9669-3408.

Matheus Iguera Cirqueira: 0000-0002-1793-3902.

Ana Beatriz Silva: 0000-0001-9815-9121.

Everson Luiz de Almeida Artifon: 0000-0003-1900-8777.

Flumignan VK, Seike MG, Souza VS, Cirqueira MI, Silva AB, Artifon ELA. Canulação biliar difícil: devemos tentar uma segunda CPRE após uma fistulotomia papilar mal-sucedida? Arq Gastroenterol. 2021;58(4):509-13.

RESUMO - Contexto - A canulação biliar de sucesso é pré-requisito para a realização da colangiopancreatografia retrógrada endoscópica (CPRE). Quando a canulação biliar não é possível, a fistulotomia com auxílio do cateter Needle-Knife (NKF) pode ser realizada. Entretanto, quando o acesso biliar não é atingido mesmo após a realização de um NKF, é possível optar-se pela interrupção do procedimento, e pela repetição da CPRE após curto intervalo de 48 horas. Objetivo - O objetivo desse estudo é analisar se a repetição da CPRE após um curto intervalo de 48 horas é efetivo em atingir o acesso biliar, quando um NKF foi realizado inicialmente sem sucesso. Métodos - Um total de 1024 pacientes com papila virgem de tratamento, submetidos à CPRE entre os anos de 2009-2019, foram retrospectivamente analisados. Canulação biliar difícil foi identificada em 238 deles, e NKF foi então realizado. Foram avaliadas as taxas de sucesso durante a canulação biliar, assim como durante a realização de NKF na primeira e segunda CPREs. A associação entre o tipo de papila, dilatação biliar e o sucesso final na realização do NFK também foi avaliada, assim como a presença de eventos adversos associados à realização do NKF. Resultados - Dentre todos os NKF realizados, acesso biliar foi inicialmente atingido em 183 $(76,8 \%)$ casos. Os $55(23,1 \%)$ casos restantes, foram submetidos a uma segunda CPRE após 48 horas e o acesso biliar foi atingido em 46 (83,6\%) deles, resultando em uma taxa final de sucesso, após a primeira e segunda CPREs, de 96,2\%. Papila localizada fora da sua posição habitual foi relacionada a menor chance de sucesso durante a realização de NKF $(P<0,05)$. Conclusão - Concluiu-se que quando o acesso biliar não pode ser atingido após a realização de um NKF, uma segunda CPRE é segura, efetiva e deve ser realizada.

Palavras-chave - CPRE; cateterização; esfincterotomia endoscópica.

\section{REFERRENCES}

1. Jin YJ, Jeong S, Lee DH. Utility of needle-knife fistulotomy as an initial method of biliary cannulation to prevent post-ERCP pancreatitis in a highly selected at-risk group: a single-arm prospective feasibility study. Gastrointest Endosc. 2016;84:80813. doi:10.1016/j.gie.2016.04.011

2. Ayoubi M, Sansoè G, Leone N, Castellino F. Comparison between needle-knife fistulotomy and standard cannulation in ERCP. World J Gastrointest Endosc. 2012;4:398-404. doi:10.4253/wjge.v4.i9.398

3. Swan MP, Bourke MJ, Williams SJ, Alexander S, Moss A, Hope R, et al. Failed biliary cannulation: clinical and technical outcomes after tertiary referral endoscopic retrograde cholangiopancreatography. World J Gastroenterol. 2011:17:4993-98. doi:10.3748/wjg.v17.i45.4993.

4. Wen J, Li T, Lu Y, Bie LK, Gong B. Comparison of efficacy and safety of transpancreatic septotomy, needle-knife fistulotomy or both based on biliary cannulation unintentional pancreatic access and papillary morphology. Hepatobiliary Pancreat Dis Int. 2019;18:73-8. doi:10.1016/j.hbpd.2018.11.007.

5. Furuya CK, Sakai P, Marinho FRT, Otoch JP, Cheng S, Prudencio LL, et al. Papillary fistulotomy $v s$ conventional cannulation for endoscopic biliary access: A prospective randomized trial. World J Gastroenterol. 2018;24:1803-11. doi:10.3748/ wjg.v24.i16.1803.

6. Lopes L, Dinis-Ribeiro M, Rolanda C. Safety and efficacy of precut needle-knife fistulotomy. Scand J Gastroenterol. 2014;49:759-65. doi:10.3109/00365521.2014.898085.

7. Halttunen J, Keränen I, Udd M, Kylänpää L. Pancreatic sphincterotomy versus needle knife precut in difficult biliary cannulation. Surg Endosc. 2009;23:745-9. doi:10.1007/s00464-008-0056-0.

8. Lopes L, Dinis-Ribeiro M, Rolanda C. Early precut fistulotomy for biliary access: time to change the paradigm of "the later, the better"? Gastrointest Endosc. 2014;80:634 41. doi:10.1016/j.gie.2014.03.014.

9. Mavrogiannis C, Liatsos C, Romanos A, Petoumenos C, Nakos A, Karvountzis G. Needle-knife fistulotomy versus needle-knife precut papillotomy for the treatment of common bile duct stones. Gastrointest Endosc. 1999;50:334-9. doi:10.1053/ ge.1999.v50.98593.

10. Testoni PA, Mariani A, Aabakken L, Arvanitakis M, Bories E, Costamagna G, et al. Papillary cannulation and sphincterotomy techniques at ERCP: European Society of Gastrointestinal Endoscopy (ESGE) Clinical Guideline. Endoscopy. 2016;48:657-83 doi:10.1055/s-0042-108641.

11. Kevans D, Zeb F, Donnellan F, Courtney G, Aftab AR. Failed biliary access following needle knife fistulotomy: is repeat interval ERCP worthwhile? Scand J Gastroenterol. 2010;45:1238-41. doi:10.3109/00365521.2010.495418.
12. Zhang QS, Han B, Xu JH, Gao P, Shen YC. Needle-knife papillotomy and fistulotomy improved the treatment outcome of patients with difficult biliary cannulation. Surg Endosc. 2016;30:5506-12. doi:10.1007/s00464-016-4914-x.

13. Donnellan F, Zeb F, Courtney G, Aftab AR. Suprapapillary needleknife fistulotomy: a safe and effective method for accessing the biliary system. Surg Endosc. 2010;24:193740. doi:10.1007/s00464-010-0881-9.

14. Archibugi L, Mariani A, Capurso G, Traini M, Petrone MC, Rossi G, et al. Needle-knife fistulotomy vs. standard biliary sphincterotomy for choledocholithiasis: common bile duct stone recurrence and complication rate. Endosc Int Open. 2019;7:E1733-E1741. doi:10.1055/a-1024-3789.

15. Zagalsky D, Lasa J. Needle-knife fistulotomy and risk of post-ERCP pancreatitis. Gastrointest Endosc. 2017;86:247-8. doi:10.1016/j.gie.2017.01.042.

16. Davee T, Garcia JA, Baron TH. Precut sphincterotomy for selective biliary duct cannulation during endoscopic retrograde cholangiopancreatography. Ann Gastroenterol. 2012;25:291-302.

17. Lee TH, Bang BW, Park SH, Jeong S, Lee DH, Kim SJ. Precut fistulotomy for difficult biliary cannulation: is it a risky preference in relation to the experience of an endoscopist? Dig Dis Sci. 2011;56:1896-03. doi:10.1007/s10620-010-1483-Z.

18. Frost JW, Kurup A, Shetty S, Fisher N. Does the presence of a trainee compromise success of biliary cannulation at ERCP? Endosc Int Open. 2017;5:E559-E562. doi:10.1055/s-0043-105579.

19. Haraldsson E, Lundell L, Swahn F, Enochsson L, Löhr JM, Arnelo U, et al. Endoscopic classification of the papilla of Vater. Results of an inter- and intraobserver agreement study. United European Gastroenterol J. 2017;5:504-10. doi: $10.1177 / 2050640616674837$.

20. Park CS, Park CH, Koh HR, Jun CH, Ki HS, Park SY, et al. Needle-knife fistulotomy in patients with periampullary diverticula and difficult bile duct cannulation. J Gastroenterol Hepatol. 2012;27:1480-3. doi:10.1111/j.1440-1746.2012.07201.x.

21. Parlak E, Suna N, Kuzu UB, Taşkiran I, Yildiz H, Torun S, et al. Diverticulum With Papillae: Does Position of Papilla Affect Technical Success? Surg Laparosc Endosc Percutan Tech. 2015;25:395-8. doi:10.1097/SLE.0000000000000130.

22. Zhang QS, Han B, Xu JH, Bao WM, Tao JL, Zhang Y. Needle knife precut papillotomy and fistulotomy for difficult biliary cannulation during endoscopic retrograde cholangiopancreatography. Digestion. 2013;88:95-100. doi:10.1159/000352027.

23. Artifon EL, Sakai P, Cunha JE, Halwan B, Ishioka S, Kumar A. Guidewire cannulation reduces risk of post-ERCP pancreatitis and facilitates bile duct cannulation. Am J Gastroenterol. 2007;102:2147-53. doi: 10.1111/j.1572-0241.2007. 